\title{
DISTRIBUTION AND HABITAT REQUIREMENTS OF THE WHITE-CLAWED CRAYFISH, AUSTROPOTAMOBIUS PALLIPES, IN A STREAM FROM THE PAYS DE LOIRE REGION, FRANCE: AN EXPERIMENTAL AND DESCRIPTIVE STUDY.
}

\author{
T. BROQUET (1), M. THIBAULT (2), A. NEVEU (3)
}

(1) Laboratoire d'Ecologie animale, UFR Sciences, Université d'Angers, 2 Bd Lavoisier, 49045 ANGERS, France. E-mail : Thomas.Broquet@etudiant.univ-rennes1.fr

(2) Association pour la Protection, l'Etude et la Promotion des Ecosystèmes Aquatiques (APEPEA), 9 rue du Gué de l'Arche, 49150 FOUGERÉ, France.

(3) UMR EQHC INRA-ENSAR, 65 rue de St Brieuc, 35000 RENNES, France.

Reçu le 21 février 2002

Accepté le 07 mars 2002
Received 21 February, 2002

Accepted 07 March, 2002

\begin{abstract}
A population of white-clawed crayfish (Austropotamobius pallipes) was studied from January to October 2000 in a stream from the Pays de Loire region (Western France). An experimental modification of habitat was performed in four stream sections by providing refuges for crayfish, followed by a regular survey of population dynamics in these areas. The crayfish distribution along the brook was studied in relation to several parameters, including water quality, current speed, brook depth and presence of refuges for crayfish. Presence of hiding places was the only habitat parameter correlated with crayfish distribution along the stream whereas colonization process in modified sections was determined by sun exposure and current speed conditions. Despite a presumably high growth rate and its ability to reach locally important densities, the population appeared to be fragmented.
\end{abstract}

Key-words: Austropotamobius pallipes, experimentation, habitat requirements, water quality, growth rate, population structure.

\section{RÉPARTITION ET HABITAT DE L'ÉCREVISSE À PATTES BLANCHES, AUSTROPOTAMOBIUS PALLIPES, DANS UN COURS D'EAU DE LA RÉGION DES PAYS-DE-LOIRE, FRANCE : UNE ÉTUDE EXPÉRIMENTALE ET DESCRIPTIVE.}

\section{RÉSUMÉ}

Une population d'écrevisses à pattes blanches (Austropotamobius pallipes) a été étudiée de janvier à octobre 2000 dans un cours d'eau de la région des Pays-de-Loire (ouest de la France). Une modification expérimentale de l'habitat consistant à créer des 
refuges disponibles pour les écrevisses a été réalisée dans quatre sections du ruisseau. Un suivi régulier de l'évolution des populations a par la suite été réalisé dans ces zones expérimentales. La répartition des écrevisses tout au long du ruisseau a par ailleurs été analysée en fonction des paramètres de qualité de l'eau, vitesse de courant, profondeur et présence de refuges pour les écrevisses. Seule la présence des abris disponibles pour les écrevisses était corrélée avec la présence d'individus tout au long du cours d'eau, tandis que la colonisation des zones expérimentales était liée à leur exposition au soleil et à la vitesse du courant. Malgré un fort taux de croissance présumé et la capacité à atteindre localement de fortes densités, la population s'est révélée fragmentée.

Mots-clés : Austropotamobius pallipes, expérimentation, paramètres de l'habitat, qualité de l'eau, taux de croissance, structure de population.

\section{INTRODUCTION}

The white-clawed crayfish, Austropotamobius pallipes (Lereboullet, 1858) is a native European species, listed as protected by the European Community. Its distribution has considerably declined over the past century (LAURENT, 1988; VIGNEUX et al., 1993) due to the combination of pollution, competition from introduced alien species (HOLDICH et al., 1993), the introduction of crayfish plague Aphanomyces astaci (HOLDICH et al., 1995), and habitat destruction or modification. This last cause has often been examined through descriptive or analytic ecological studies dealing with a large number of environmental variables (e.g. FOSTER, 1995; SMITH et al., 1996). This study seeks to establish key ecological parameters for $A$. pallipes population dynamics through experimental modification of its habitat in a small brook (the Brocard). The response of individuals in the perturbed area was analysed to identify key habitat features for $A$. pallipes, and this work was completed by a descriptive study of its habitat requirements all along its distribution in the concerned brook. The main objectives of this study were to determine the status of the white-clawed crayfish population and to assess experimentally the role of habitat's attributes on crayfish occurrence.

\section{MATERIAL AND METHODS}

\section{Study area}

Fieldwork was conducted from January to October 2000 in the Brocard. This brook is located in the eastern part of the Pays-de-Loire region in France (Figure 1). The study site is restricted to the upper part of the stream $(6 \mathrm{~km})$, which runs towards a tributary of the river Loire. The brook varied from 10 to $85 \mathrm{~cm}$ in depth (mean depth $=24 \mathrm{~cm}$ ) and from 1 to $4 \mathrm{~m}$ in width (mean width $=2.5 \mathrm{~m}$ ). The Brocard has its source in a calcareous region, and shows high mineralization $\left(120 \mathrm{ppm}\right.$ of $\left.\mathrm{Ca}^{2+}\right)$. The water temperature in the study site (Figure 2) varied from $7.5^{\circ} \mathrm{C}$ (in December) to $20^{\circ} \mathrm{C}$ (in July), and the spring provided a constant supply of water. The mean flow rate was $0.37 \mathrm{~m} . \mathrm{s}^{-1}$. The substrate was dominated by sand and clay, with some pebbles and cobbles.

Several species of aquatic macrophytes were present (Callitriche palustris, Nasturtium officinale, Mentha aquatica), and two species of crayfish have been observed in the Brocard: white-clawed crayfish (Austropotamobius pallipes) was present upstream, and an alien species, the American crayfish (Orconectes limosus) was present downstream. 


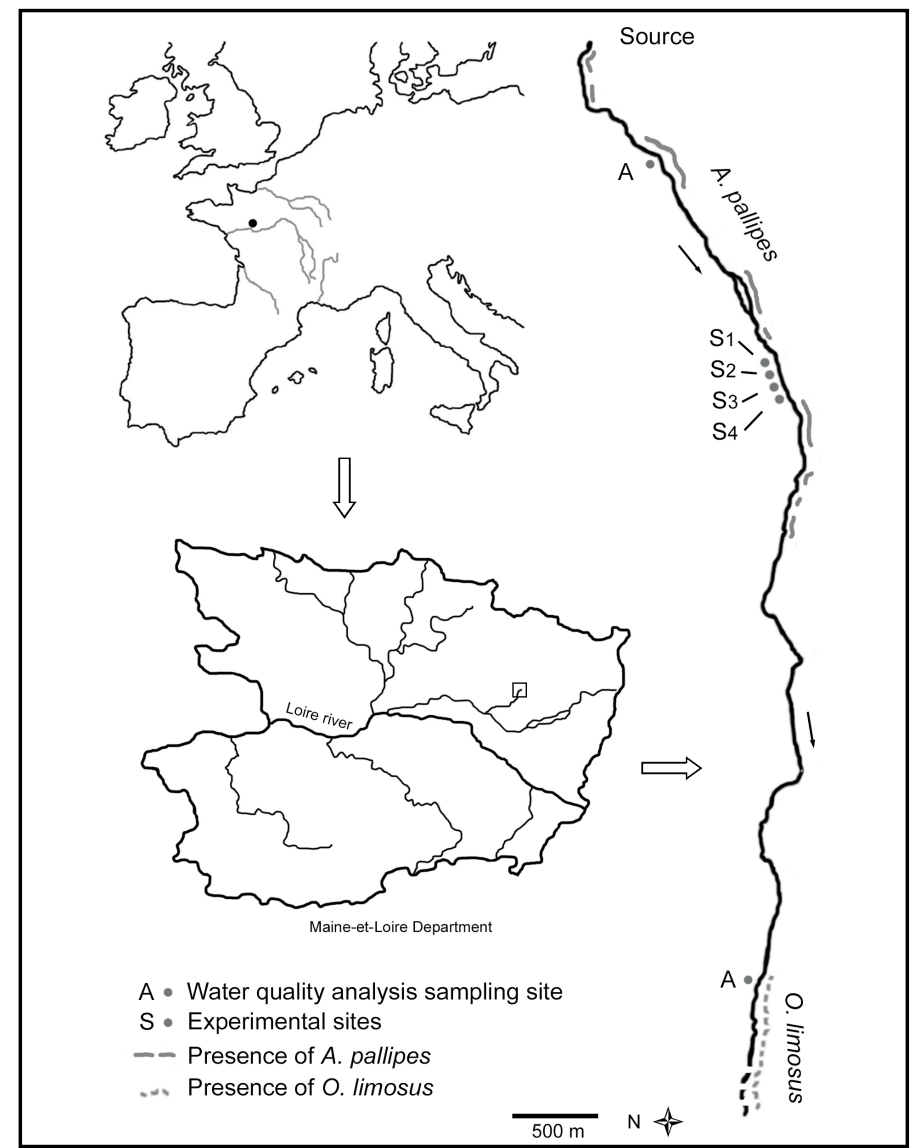

Figure 1

Distribution of crayfish among the Brocard brook, determined through an exhaustive hand-capture survey in May 2000.

Figure 1

Répartition des écrevisses dans le ruisseau le Brocard, déterminée en mai 2000 par une campagne exhaustive de capture à la main.

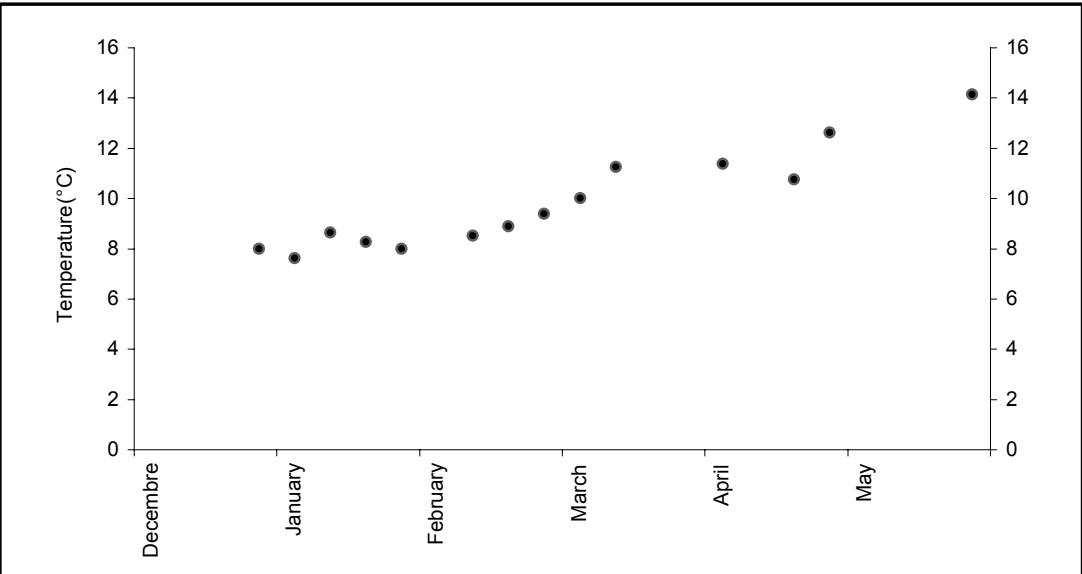

Figure 2

Water temperature recorded weekly from December to May 2000.

Figure 2

Température de l'eau mesurée une fois par semaine de décembre à mai 2000. 


\section{Water quality}

The chemical quality of water was analysed (Table I). Two samples of water were taken in the brook, respectively at $600 \mathrm{~m}$ (presence of Austropotamobius pallipes) and at $5.7 \mathrm{~km}$ (presence of Orconectes limosus) from the source (Figure 1). Sampling took place four times in year 1999. All analyses were performed by the staff of the DIREN BretagnePays-de-Loire. Water quality was assessed by consideration of 18 physico-chemical parameters distributed in 7 classes: a) mineralization, b) particles in suspension, c) organic and oxidizible matter, d) nitrates, e) other nitrogenous compounds, f) phosphorous residues and $\mathrm{g}) \mathrm{pH}$.

\section{Table I}

Mean levels of water quality computed for $A$. pallipes area and $\boldsymbol{O}$. limosus area (four sampling periods: March, June, September and December).

\section{Tableau I}

Valeurs moyennes de qualité de l'eau calculées pour la zone occupée par $A$. pallipes et la zone occupée par 0 . limosus (quatre périodes d'échantillonnage : mars, juin, septembre et décembre).

\begin{tabular}{|c|c|c|c|c|}
\hline & $\begin{array}{c}\text { A. pallipes } \\
\text { (mean values) }\end{array}$ & $\begin{array}{c}\text { O. limosus } \\
\text { (mean values) }\end{array}$ & T Student & $\mathrm{p}$ \\
\hline \multicolumn{5}{|l|}{ Mineralization } \\
\hline cond. $(\mu \mathrm{S} / \mathrm{cm})$ & 617.50 & 650.00 & 0.888 & 0.440 \\
\hline $\mathrm{Ca}^{2+}(\mathrm{ppm})$ & 125.33 & 105.00 & 1.641 & 0.242 \\
\hline $\mathrm{Mg}^{2+}(\mathrm{ppm})$ & 12.68 & 16.85 & 0.455 & 0.668 \\
\hline \multicolumn{5}{|c|}{ Particles in suspension } \\
\hline M.E.S. (mg/L) & 7.00 & 21.75 & 4.435 & 0.021 \\
\hline \multicolumn{5}{|c|}{ Organic and oxidizible matter } \\
\hline $\mathrm{O}_{2}(\mathrm{mg} / \mathrm{L})$ & 8.58 & 10.60 & 1.514 & 0.190 \\
\hline$\%$ sat. $\mathrm{O}_{2}$ & 81.50 & 102.00 & 1.972 & 0.1057 \\
\hline B.O.D.5 $\left(\mathrm{mg} / \mathrm{LO}_{2}\right)$ & 1.63 & 3.60 & 1.782 & 0.173 \\
\hline C.O.D. (mg/LO & 10.25 & 24.25 & 3.416 & 0.042 \\
\hline \multicolumn{5}{|c|}{ Nitrogenous compounds } \\
\hline $\mathrm{NH}_{4}^{+}\left(\mathrm{mg} / \mathrm{L} \mathrm{NH}_{4}\right)$ & 0.06 & 0.09 & 1.400 & 0.256 \\
\hline NK (mg/L N) & 0.50 & 1.03 & 2.849 & 0.046 \\
\hline $\mathrm{NO}_{2}^{-}\left(\mathrm{mg} / \mathrm{L} \mathrm{NO}_{2}\right)$ & 0.06 & 0.22 & 4.164 & 0.014 \\
\hline \multicolumn{5}{|l|}{ Nitrates } \\
\hline $\mathrm{NO}_{3}^{-}\left(\mathrm{mg} / \mathrm{L} \mathrm{NO}_{3}\right)$ & 25.75 & 29.80 & 0.5321 & 0.637 \\
\hline \multicolumn{5}{|c|}{ Phosphorous residues } \\
\hline $\mathrm{P}$ total $(\mathrm{mg} / \mathrm{L})$ & 0.05 & 0.13 & 1.834 & 0.164 \\
\hline $\mathrm{PO}_{4}^{-}\left(\mathrm{mg} / \mathrm{L} \mathrm{PO}_{4}\right)$ & 0.10 & 0.26 & 1.461 & 0.240 \\
\hline $\mathrm{pH}$ & 7.45 & 8.05 & 3.795 & 0.009 \\
\hline
\end{tabular}

Biological quality was also investigated at both sites chosen for water quality analyses, where an I.B.G.N. (Indice Biologique Global Normalisé) value was calculated. According to the protocol AFNOR (AGENCE DE L'EAU, 1992), sampling of benthic macrofauna was carried out on different substrates, and with several current speeds (eight samples per study site). Identification of invertebrate species was performed under a binocular microscope. The collected invertebrates reflected the biological water quality on a scale from 1 to 20, where 1 indicates very poor quality (pollution) and 20 represents highest quality. 


\section{Crayfish distribution}

All sampling for this study was performed using hand nets $(40 \times 40 \mathrm{~cm}, 4 \mathrm{~mm}$ mesh) and hand capture methods. Distribution of species (Orconectes limosus and Austropotamobius pallipes) was determined using this procedure all along the study site in May 2000. At the same time, several habitat parameters were described for each area occupied by Austropotamobius pallipes and for any area where no crayfish was detected: these were current speed, brook depth, and presence of refuges for crayfish. Each individual caught was sexed and measured (Total Length TL).

\section{Population density}

A mark-recapture method was used in a $80 \mathrm{~m}^{2}$ area in order to assess the population density in early May. Crayfish were marked by tail clipping according to the method of VIGNEUX and VIGNEUX (1981), and the second capture took place the following day. By this means, only one of the basic assumptions of mark-recapture methods was not perfectly respected (marked crayfish may not become perfectly mixed within the population, but we assume that released individuals become randomly mixed within a group of crayfish).

Chapman's estimate of the population size was used (SEBER, 1982):

$$
N=\frac{(M+1) \cdot(n+1)}{(m+1)}-1
$$

$\mathrm{N}=$ estimate of population size

$M=$ number marked (first capture)

$\mathrm{n}=$ total number of crayfish (second capture)

$\mathrm{m}=$ number recaptured marks

The variance of $\mathrm{N}$ is computed by the equation:

$$
\operatorname{Var}(M)=\frac{(M+1)(n+1)(M-m)(n-m)}{(m+1)^{2} \cdot(m+2)}
$$

\section{Experimental habitat modification}

Four experimental areas (20 meters long) without any visible refuges or hiding places for crayfish were chosen (Figure 1):

- site 1: low current speed; sunshine (i.e. poor riparian vegetation),

- site 2: high current speed; sunshine,

- site 3: high current speed; shaded (i.e. considerable vegetation cover),

- site 4: low current speed; shaded.

An exhaustive survey performed in January allowed us to believe with good odds (no evidence of shelters, high catching effort) that these four study areas were unoccupied by crayfish at the beginning of the experiment. Then half of each habitat was modified (10 meters long) by adding rocks providing refuges for crayfish. By this way, each site was divided in two parts of 10 meters: one without any modification and the other strewn with stones. Sampling was performed each month from January to May 2000. All captured crayfish were sexed, measured (total length: TL), individually marked by tail-clipping in accordance with a code, and then immediately released at the same place. 


\section{RESULTS}

\section{Water quality}

The quality of the area occupied by the white-clawed crayfish was significantly higher (alternate t-test) than the quality of water where Orconectes limosus was evidenced for five parameters (Table I): suspended matter $(p=0.021)$, C.O.D. $(p=0.042)$, NK $(p=0.046)$, $\mathrm{NO}_{2}^{-}(\mathrm{p}=0.041)$ and $\mathrm{pH}(\mathrm{p}=0.009)$. Moreover, estimated biological quality (Tables II and III) was poorer in the part of the brook occupied by Orconectes limosus (I.B.G.N. value $=11$ ) than upstream (I.B.G.N. value $=13$ ).

\section{Table II}

List of macroinvertebrates (eight samples) leading to the computation of IBGN value for $A$. pallipes area.

\section{Tableau II}

Liste des macroinvertébrés (huit échantillons) permettant le calcul de la valeur d'IBGN pour l'aire occupée par $A$. pallipes.

\begin{tabular}{|c|c|c|c|c|c|c|c|c|c|}
\hline \multicolumn{10}{|c|}{ Surber samples } \\
\hline & 1 & 2 & 3 & 4 & 5 & 6 & 7 & 8 & $\begin{array}{c}\text { Total } \\
\text { number }\end{array}$ \\
\hline \multicolumn{10}{|l|}{ TRICHOPTERA } \\
\hline Glossosomatidae & & 5 & & & & 3 & 2 & & 10 \\
\hline Limnephilidae & 24 & 5 & & 6 & & & 16 & & 51 \\
\hline Sericostomatidae & 1 & & & & & & & & 1 \\
\hline \multicolumn{10}{|l|}{ EPHEMEROPTERA } \\
\hline Baetidae & 11 & 56 & 25 & 5 & 4 & 24 & 35 & & 160 \\
\hline \multicolumn{10}{|l|}{ COLEOPTERA } \\
\hline Elmidae & 4 & 9 & 12 & 3 & 3 & 5 & 2 & & 38 \\
\hline Helodidae & 1 & & & & & & & & 1 \\
\hline \multicolumn{10}{|l|}{ DIPTERA } \\
\hline Anthomyidae & & & 1 & & & & & & 1 \\
\hline Chironomidae & & 14 & 2 & 1 & 2 & 2 & 23 & 12 & 56 \\
\hline Limoniidae & & & & & 2 & 9 & & & 11 \\
\hline Simulidae & 350 & 147 & & 8 & 5 & 7 & 49 & 2 & 568 \\
\hline \multicolumn{10}{|l|}{ ODONATES } \\
\hline Calopterigidae & & & & 3 & & & & & 3 \\
\hline \multicolumn{10}{|l|}{ MEGALOPTERA } \\
\hline Sialidae & & & & & 1 & & & & 1 \\
\hline \multicolumn{10}{|l|}{ CRUSTACEA } \\
\hline Gammaridae & 350 & 200 & 185 & 30 & 120 & 400 & 150 & 48 & 1483 \\
\hline \multicolumn{10}{|l|}{ MOLLUSCA } \\
\hline Sphaeriidae & & 5 & & & 25 & & & & 30 \\
\hline Ancylidae & & 2 & & & & & & & 2 \\
\hline Hydrobiidae & & 25 & & & & & & & 25 \\
\hline Limnaeidae & & 2 & & & & & 1 & & 3 \\
\hline \multicolumn{10}{|l|}{ ACHETA } \\
\hline Erpobddellidae & & & & & 1 & & 1 & & 2 \\
\hline Glossiphonidae & & & & & & & 1 & & 1 \\
\hline \multicolumn{10}{|l|}{ TRICLADES } \\
\hline Planariidae & & 13 & 12 & 1 & & & 107 & 25 & 158 \\
\hline OLIGOCHETA & & & 5 & & & 2 & & 2 & 9 \\
\hline Number of taxa & 21 & & & & & & & & \\
\hline Number of individuals & 2614 & & & & & & & & \\
\hline I.B.G.N. value & 13 & & & & & & & & \\
\hline
\end{tabular}




\section{Table III}

List of macroinvertebrates (eight samples) leading to the computation of IBGN value for $\boldsymbol{O}$. limosus area.

\section{Tableau III}

Liste des macroinvertébrés (huit échantillons) permettant le calcul de la valeur d'IBGN pour l'aire occupée par 0 . limosus.

\begin{tabular}{|c|c|c|c|c|c|c|c|c|c|}
\hline & & Su & r sa & les & & & & & \\
\hline & 1 & 2 & 3 & 4 & 5 & 6 & 7 & 8 & $\begin{array}{c}\text { Total } \\
\text { number }\end{array}$ \\
\hline TRICHOPTERA & & & & & & & & & \\
\hline Hydropsychidae & & & 31 & 3 & 1 & & & 1 & 36 \\
\hline Limnephilidae & & 6 & 1 & & 1 & & & & 8 \\
\hline Sericostomatidae & & & 1 & & & & & & 1 \\
\hline EPHEMEROPTERA & & & & & & & & & \\
\hline Baetidae & 57 & 2 & 14 & 3 & 5 & 1 & 1 & 20 & 103 \\
\hline Ephemeridae & & & & & & 8 & 8 & & 16 \\
\hline COLEOPTERA & & & & & & & & & \\
\hline Elmidae & & 14 & 37 & 68 & & 1 & 14 & 1 & 135 \\
\hline DIPTERA & & & & & & & & & \\
\hline Chaoboridae & & & & & & 1 & & & 1 \\
\hline Chironomidae & 3 & 2 & & 1 & 3 & & & 4 & 13 \\
\hline Simulidae & 3 & & 1 & 2 & 3 & 5 & & & 14 \\
\hline ODONATES & & & & & & & & & \\
\hline Calopterigidae & 2 & & & & & & & & 2 \\
\hline CRUSTACEA & & & & & & & & & \\
\hline Gammaridae & 156 & 72 & 73 & 181 & 24 & 53 & 34 & 128 & 721 \\
\hline Astacidae & & & & & 1 & & & & 1 \\
\hline MOLLUSCA & & & & & & & & & \\
\hline Sphaeriidae & 1 & 4 & 2 & 4 & & 5 & 100 & & 116 \\
\hline TRICLADES & & & & & & & & & \\
\hline Planariidae & 5 & & & & & & & & 5 \\
\hline OLIGOCHETA & & & & & & 2 & 26 & 2 & 30 \\
\hline Number of taxa & 15 & & & & & & & & \\
\hline Number of individuals & 1202 & & & & & & & & \\
\hline I.B.G.N. value & 11 & & & & & & & & \\
\hline
\end{tabular}

\section{Crayfish distribution}

Austropotamobius pallipes populations were found over $3 \mathrm{~km}$ (starting from the source). An apparently unoccupied portion of the stream (2.7 km long) separated the last $A$. pallipes group from another crayfish species, the American crayfish (O. limosus), present downstream (no crayfish captured during the exhaustive survey, with a similar capture effort). The distribution of Austropotamobius pallipes in the first part of the brook ( $3 \mathrm{~km})$ was not regular (Figure 1).The species was distributed among nine patches, representing $1700 \mathrm{~m}$ of the brook (i.e. $57 \%$ of the $3 \mathrm{~km}$ area for A. pallipes). Presence of hiding places was always correlated with presence of crayfish. Such places where always one of three classes: rocks, tree roots (Alnus glutinosus, Salix caprea, Fraxinus excelsior) and cavities under river banks. Crayfish presence along the brook was not significantly related to depth (Mann-Whitney $U$ statistic $=66.5, p=0.29)$ nor to current speed $(U=61, p=0.19)$. 


\section{Population structure}

The size of the population studied in a $80 \mathrm{~m}^{2}$ area was estimated at $468(\sigma=120 ; M=66, n=69, m=9)$ ind. The density of the population at that site was about $5.8( \pm 1.5)$ ind. $\mathrm{m}^{-2}$. The 271 captures carried out in May during the exhaustive survey allowed us to determine population organization. The capture method allowed us to detect the first year-class, and polymodal size-frequency histograms were constructed from this sample (Figure 3). The modal size classes were about $35 \mathrm{~mm} \mathrm{(1+)}$ and $65 \mathrm{~mm} \mathrm{(2+)} \mathrm{total}$ length, whereas a third age class (3+) is less clearly identified. The sex-ratio calculated for each age class is well-balanced, respectively $1: 1.1(1+, n=204), 1: 1.1(2+, n=60)$ and $1: 1.3(3+, \mathrm{n}=7)$.

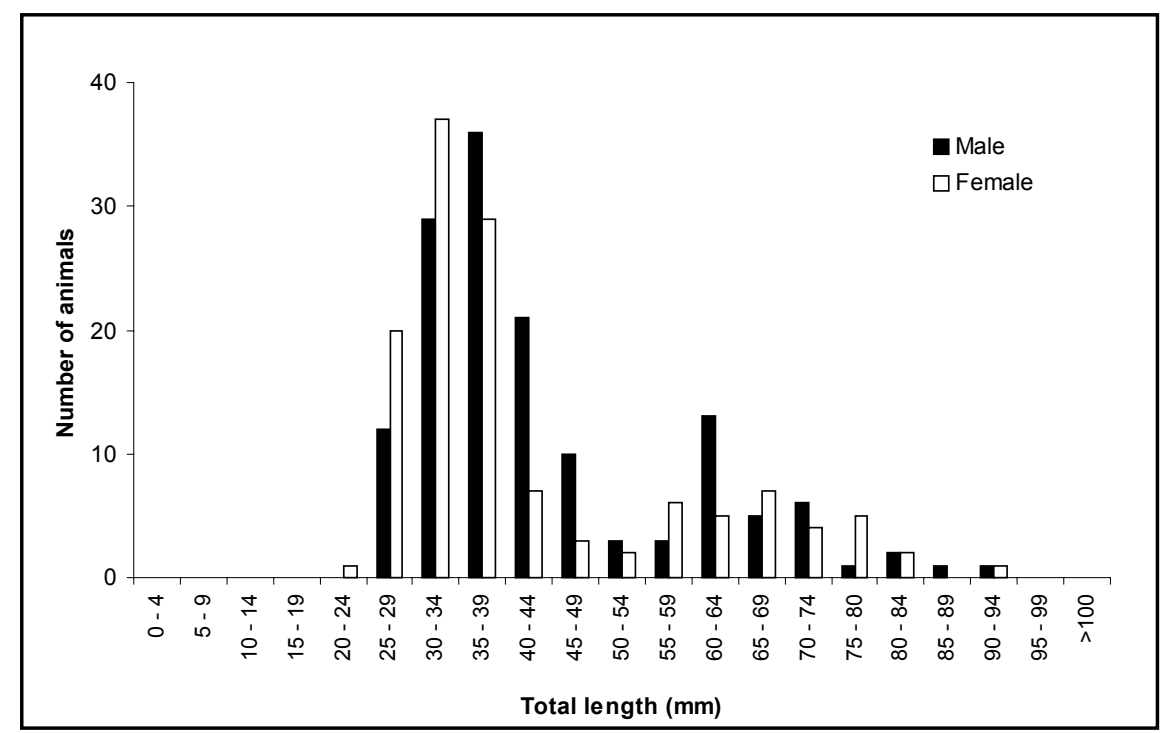

\section{Figure 3}

Polymodal size-frequency histograms of 271 A. pallipes captured in May 2000, in $5 \mathrm{~mm}$ intervals of total length (TL).

\section{Figure 3}

Histogramme de structure de taille pour 271 A. pallipes capturées en mai 2000, intervalles de $5 \mathrm{~mm}$ de longueur totale (TL).

\section{Experimental habitat modification}

All crayfish catches from January to May 2000 are presented in Table IV. No crayfish were caught in unmodified part of each experimental site whereas 43 crayfish were totally captured in modified portions. Two of the 6 individuals caught more than once were found in different places at each capture (two of them moved upstream). Experimental site number 4 (low current speed, shade) held most Austropotamobius pallipes (31 ind.) whereas only 6 crayfish were caught in site 3 (high current speed, shade). Both sites 1 and 2 (sunshine, with low or high current speed) had very low occupancy. We were not able to determine the origin of individuals (the two nearest patch were located $50 \mathrm{~m}$ downstream and about $100 \mathrm{~m}$ upstream) but given the scale of the study area, we assume that colonizing individuals had the same probability to be find in every experimental site. This colonization scheme differed significantly from what was expected with randomly distributed colonizing individuals $\left(\mathrm{Chi}^{2}=68.3\right.$; ndf $\left.=3 ; \mathrm{p}<0.0001\right)$. 
Table IV

Catch data from the experimental area after habitat modification (site 1, low current speed; site 2, high current speed; sites 3 and 4, shaded, respectively high and low current speed).

Tableau IV

Captures réalisées dans l'aire d'étude expérimentale après modification expérimentale de l'habitat (site 1, faible courant ; site 2, fort courant ; sites 3 et 4, à l'ombre, respectivement fort et faible courant).

\begin{tabular}{|c|c|c|c|c|c|c|c|}
\hline & & $\begin{array}{l}\text { January } \\
\text { installation }\end{array}$ & February & March & April & May & $\begin{array}{c}\text { Total } \\
\text { number }\end{array}$ \\
\hline \multirow{2}{*}{ Site 1$\}$} & $\begin{array}{l}\text { unmodified } \\
\text { portion }\end{array}$ & 0 & 0 & 0 & 0 & 0 & 0 \\
\hline & Exp & 0 & 0 & 0 & $\begin{array}{c}0 \text { male } \\
1 \text { female }^{\star}\end{array}$ & $\begin{array}{c}0 \text { male } \\
1 \text { female }^{*}\end{array}$ & 2 \\
\hline \multirow{2}{*}{ Site 2\{} & $\begin{array}{l}\text { unmodified } \\
\text { portion }\end{array}$ & 0 & 0 & 0 & 0 & 0 & 0 \\
\hline & Exp & 0 & 0 & 0 & $\begin{array}{c}0 \text { male } \\
1 \text { female }\end{array}$ & 0 & 1 \\
\hline \multirow{2}{*}{ Site 3$\}$} & $\begin{array}{l}\text { unmodified } \\
\text { portion }\end{array}$ & 0 & 0 & 0 & 0 & 0 & 0 \\
\hline & Exp & 0 & 0 & $\begin{array}{c}1 \text { male } \\
0 \text { female }\end{array}$ & $\begin{array}{c}1 \text { male } \\
0 \text { female }\end{array}$ & $\begin{array}{c}3 \text { males }\left(1^{\star}\right) \\
1 \text { female }\end{array}$ & 6 \\
\hline \multirow{2}{*}{ Site 4} & $\begin{array}{l}\text { unmodified } \\
\text { portion }\end{array}$ & 0 & 0 & 0 & 0 & 0 & 0 \\
\hline & Exp & 0 & $\begin{array}{c}4 \text { males } \\
5 \text { females }\end{array}$ & $\begin{array}{l}3 \text { males } \\
1 \text { female }\end{array}$ & $\begin{array}{c}5 \text { males } \\
5 \text { females }\end{array}$ & $\begin{array}{c}8 \text { males }\left(1^{\star}\right) \\
3 \text { females }\left(2^{\star}\right)\end{array}$ & 34 \\
\hline \multicolumn{2}{|c|}{ Total number } & 0 & 9 & 5 & 13 & 16 & 43 \\
\hline
\end{tabular}

* marked

\section{DISCUSSION}

\section{Habitat requirements}

As in our study area, white-clawed crayfish distribution in brooks is often heterogeneous (BOHL, 1997), crayfish density variations being closely related to habitat characteristics at different scales (NEVEU, 2000). This species is mostly found in high quality waters (ANDRÉ, 1960; LAURENT, 1988; REYNOLDS, 1997) and is also generally thought to require such conditions. In the Brocard, the chemical and biological quality of the area occupied by white-clawed crayfish significantly differed from the quality of water where Orconectes limosus was found. However, some detailed studies showed that Austropotamobius pallipes can withstand certain chemical constraints (LAURENT, 1985; FOSTER and TURNER, 1993; TROSCHEL, 1997). Most water quality parameters show indirect consequences on populations (FOSTER and TURNER, 1993; FOSTER, 1995), through a diminution of trophic resources (e.g. effect of nitrates and other nitrogenous matters, phosphorous residues) or by reducing the ability of crayfish to resist chemical alteration (e.g. effect of dissolved oxygen). White-clawed crayfish presents a fair tolerance margin in both cases. Other parameters like $\mathrm{pH}$ and mineralization have a direct effect on crayfish occurrence (JAY and HOLDICH, 1977; FOSTER, 1995) but these key-factors were optimal in our study area and not significantly different between the areas respectively occupied by the two species. Hence, crayfish distribution can not be explained by water quality variation in the Brocard. 
The physical attributes of habitat are most likely to explain the distribution of Austropotamobius pallipes (e.g. NEVEU, 2000). The presence of refuges for crayfish appears to be a critical parameter, mostly explaining the distribution of groups of individuals among the brook. Moreover, the absence of $A$. pallipes downstream corresponded to a clear transformation of habitat conditions due to the channelization of the river bed. The difference between both I.B.G.N. values was weak, but some macroinvertebrate species evidenced notable habitat differences between sites (e.g. Ancylidae and Hydrobiidae revealed the presence of cobbles in A. pallipes area). The experimentally modified habitat also showed a very rapid colonization by crayfish. This imply that refuges constitute a major habitat characteristic, mainly determining the ability of a brook to support a crayfish population (SMITH et al., 1996). Crayfish presence along the brook was not significantly related to other habitat features such as light exposure and current speed but their presence in experimental sites seemed to depend on these parameters. These contrasting results did not permit us to draw conclusions on the impact of light and current speed. This may be partially explained by the fact that colonization events are dependent on several factors, not all evaluated here (e.g. behavioural parameters, distance from the nearest dispersion source).

\section{Population structure}

The estimated density of $5.8 \mathrm{ind} / \mathrm{m}^{2}$ is similar to values obtained in different studies of Austropotamobius pallipes populations (e.g. GRANDJEAN et al., 2000). However, this density was calculated in a delimited area of the brook where conditions were naturally optimal. It does not represent the overall mean density of crayfish, highly variable from one occupated patch to another.

Age classes determined by the analysis of the length-frequency histogram gave evidence of a high growth rate for crayfish in the study area. Hatching in June, crayfish in the first year-class (called $1+$ ) would be almost one-year old at the sampling date. We infer that such individuals compose the first size-class observed (mode $35 \mathrm{~mm} \mathrm{TL}$ ), given that no crayfish smaller than $24 \mathrm{~mm}$ was found, and that the same capture method allowed us to find some newly-hatched individuals $(10 \mathrm{~mm} \mathrm{TL})$ in June of the preceding year. Moreover, our interpretation is consistent with observations of high growth rate made on different species under certain conditions: noble crayfish (Astacus astacus) are able to reach 40-50 $\mathrm{mm}$ TL during the first fall $(0+)$, whereas American crayfish (Orconectes limosus) can reach $60-80 \mathrm{~mm}$ TL in the same time $(0+)$, and crayfish (Astacus leptodactylus) more than $90 \mathrm{~mm}$ (NEVEU, pers. obs). Although this analysis is based on only one sampling period, the population structure can be compared with data from the literature. The results of such studies are not easily reliable since the methods (especially sampling time) are different. However, analyses of modal size classes imply that the crayfish population in the Brocard presented a higher growth rate than estimated in three other study areas (BROWN and BOWLER, 1978; PRATTEN, 1980; NEVEU, 1996;) and similar to the results obtained for three populations in Southern France (ROQUEPLO, 1997). Four parameters have been proposed to explain the variability of crayfish growth: temperature (e.g. PRATTEN, 1980), mineralization (ANDRÉ, 1960; LOWERY, 1988), trophic resources and density (BROWN and BOWLER, 1978; PRATTEN, 1980). The trophic resources are very difficult to evaluate and their impact on growth rate have not yet been estimated. The density of crayfish is proved to have consequences on productivity in laboratory or farming conditions, but is less likely to occur in natural populations. Crayfish are thought to require high water temperatures to optimise their growth rate (WHITELEY et al., 1997). However, the temperature in the Brocard is not high enough to explain our results. In contrast, we hypothesize that the mineralization parameter, which is of primary importance in crayfish growth (LOWERY, 1988; GARCIA-ARBERAS and RALLO, 2000), can explain our result in the Brocard, where a mean $\mathrm{Ca}^{2+}$ concentration of $120 \mathrm{ppm}$ was scored. The $\mathrm{Ca}^{2+}$ concentration noted in the above mentioned literature varied from 3 to $61 \mathrm{ppm}$, with growth rates apparently ranked according to these levels of mineralization. 


\section{CONCLUSION}

Contrary to our expectations, water quality factors did not explain the distribution of crayfish in the studied stream. Although chemical and biological water quality significantly differed between Orconectes limosus and Austropotamobius pallipes areas, the literature suggests that these factors can not be responsible for the distribution of the species in our site. Rather, the physical attributes of the habitat, and especially the occurrence of refuges explained the presence of crayfish. More detailed ecological studies are needed to elucidate the effect of light, current speed and stream depth on crayfish abundance. More notably, in spite of the supposed high growth rate and the ability of $A$. pallipes to reach a great density, the crayfish population appeared to be fragmented, although crayfish movements (downstream and upstream) were recorded. If such movements between crayfish groups are limited, this fragmentation is likely to increase the extinction risk for this species when restricted in a limited area. The results of this study confirmed the overriding importance of riparian habitats and river beds conservation for endangered freshwater species such as the white-clawed crayfish.

\section{ACKNOWLEDGEMENTS}

Thanks are due to the staff of the « DIREN Bretagne-Pays de Loire » who carried out water quality analyses. Fabrice Denis efficiently performed the IBGN determination and his participation in sampling was helpful. We wish also to acknowledge Thierry Lodé (University of Angers), the "Fédération du Maine-et-Loire pour la pêche et la protection du milieu aquatique " and the CSP (Conseil Supérieur de la Pêche, represented by Marc Royer). This study was initiated by the "Comité d'Expansion du Baugeois " and supported by a grant from the CRD CODA (Conseil Régional de Développement et Comité Départemental d'Aménagement).

\section{REFERENCES}

AGENCE DE L'EAU, 1992. Indice Biologique Normalisé I.B.G.N. NF T 90350 GUIDE TECHNIQUE, $68 \mathrm{p}$.

ANDRÉ M., 1960. Les écrevisses françaises. Paris, Lechevalier, 293 p.

BOHL E., 1997. An isolated population of the white-clawed crayfish (Austropotamobius pallipes) in the principality of Liechenstein. Bull. Fr. Pêche Piscic., 347, 701-712.

BROWN D.J., BOWLER K., 1978. The relationship between size and age throughout the life cycle in Austropotamobius pallipes. Freshwater Crayfish, 4, 35-42.

FOSTER J., 1995. Factors influencing the distribution and abundance of the crayfish Austropotamobius pallipes (Lereboullet) in Wales and the Marches, UK. Freshwater Crayfish, 8, 78-98.

FOSTER J., TURNER C., 1993. Toxicity of field simulated farm waste episodes to the crayfish Austropotamobius pallipes (Lereboullet): elevated ammonia and reduced dissolved oxygen concentrations. Freshwater Crayfish, 9, 249-258.

GARCIA-ARBERAS L., RALLO A., 2000. Survival of natural populations of Austropotamobius pallipes in rivers in Bizkaia, Basque country (north of Iberian peninsula). Bull. Fr. Pêche Piscic., 356, 17-30.

GRANDJEAN F., CORNUAULT B., ARCHAMBAULT S., BRAMARD M., OTREBSKY G., 2000. Life history and population biology of the white-clawed crayfish, Austropotamobius pallipes pallipes, in a brook from the Poitou-Charentes region (France). Bull. Fr. Pêche Piscic., 356, 55-70.

HOLDICH D.M., REEVE I.D., ROGERS W.D., 1993. Introduction and spread of alien crayfish in British waters - Implications for native crayfish populations. Freshwater Crayfish, 8, 99-112. 
HOLDICH D.M., READER J.P., ROGERS W.D., HARLIOGLU M., 1995. Interactions between three species of crayfish (Austropotamobius pallipes, Astacus leptodactylus and Pacifastacus leniusculus). Freshwater Crayfish, 10, 46-56.

JAY D., HOLDICH D.M., 1977. The pH tolerance of the crayfish Austropotamobius pallipes (Lereboullet). Freshwater Crayfish, 3, 363-370.

LAURENT P.J., 1985. Une station d'écrevisses à pieds blancs : Austropotamobius pallipes Lere. (Decapoda - Astacidae) en zone périurbaine. Bulletin de la société linnéenne de Lyon, 3, 77-88.

LAURENT P.J., 1988. Austropotamobius pallipes and A. torrentium, with observations on their interactions with other species in Europe. In: Freshwater crayfish (HOLDICH D.M., LOWERY R.S., Eds.), 341-365. London, The University Press.

LOWERY R.S., 1988. Growth, moulting and reproduction. In: Freshwater crayfish (HOLDICH D.M., LOWERY R.S., Eds.), 83-113. London, Cambridge University Press.

NEVEU A., 1996. Caractéristiques démographiques de stocks résiduels de l'écrevisse à pattes blanches, Austropotamobius pallipes (Astacidae), en Normandie. Cybium, 20 (3), 75-93.

NEVEU A., 2000. Répartition en fonction de la structure des habitats : stabilité et variabilité au cours de cinq années. Bull. Fr. Pêche Piscic., 356, 99-122.

PRATTEN D.J., 1980. Growth of the crayfish Austropotamobius pallipes (Crustacea: Astacidae). Freshwater Biology, 10, 401-412.

REYNOLDS J.D., 1997. The present status of freshwater crayfish in Ireland. Bull. Fr. Pêche Piscic., 347, 693-700.

ROQUEPLO C., 1997. Etude de populations d'écrevisses à pattes blanches (Austropotamobius pallipes Lereboullet) en cours d'eau, soumises à une pêche de loisir. L'astaciculteur de France, 51, 59-69.

SEBER G.A.F., 1982. The estimation of animal abundance and related parameters, Second Edition. New York, Mc Millan, 420 p.

SMITH G.R.T., LEARNER M.A., SLATER F.M., FOSTER J., 1996. Habitat features important for the conservation of the native crayfish Austropotamobius pallipes in Britain. Biological conservation, 75, 239-246.

TROSCHEL H.J., 1997. Distribution and ecology of Austropotamobius pallipes in Germany. Bull. Fr. Pêche Piscic., 347, 639-647.

VIGNEUX D., VIGNEUX E., 1981. Gestion de peuplements astacicoles - repeuplements. Bull. Fr. Pêche Piscic., 281, 169-184.

VIGNEUX E., KEITH P., NOEL P., 1993. Atlas préliminaire des Crustacés Décapodes d'eau douce de France. Paris, $55 \mathrm{p}$.

WHITELEY N.M., TAYLOR E.W., EL HAJ A.J., 1997. Seasonal and latitudinal adaptation to temperature in crustaceans. Journal of thermal biology, 22 (6), 419-427. 